\title{
HOW TO READ LAW
}

\author{
Marko Trajković \\ University of Niš, Faculty of Law
}

Where does the reading of law come from? The answer lies in the following: the imperative and pressure. After the imperative postulations, it is very important to estimate how law is interpreted by reason. Therefore, completely unexpectedly, we open the issue of the construction, reading and interpretation of law with the issue of pain, which is often very skillfully avoided. Pain may come out of the construction, reading and interpretation of law because law is not created just for the sake of creating, but in order to be applied, or for people to behave in compliance with it. In this way, it can be a source of immeasurable pain.

Key Words: law, value, value reading, interpretation, construction

\section{Introduction}

Is it justified to stand behind the following idea: "Just votes for unjust laws"? ${ }^{1}$ History

demonstrates very impressively the horrors of such an approach. Therefore, we need the idea of the value reading of law, since: "Dealing with conflicts of interest is inherent in a lawyer's life" according to Geoffrey Hazard. ${ }^{2}$ From such everyday life, a manlawyer must come up with a solution that corresponds to the idea of the UN Commission on Human Rights, and we quote the following: "In 1994, the UN Commission on Human Rights recorded that it was "convinced that an independent and impartial judiciary and an independent legal profession are essential pre-requisites for the protection of human rights and for the ensuring that there is no discrimination in the administration of justice."

The inseparability of law from the society indicates an association between value and moral life and reading of law, since: "It is the morality of the Good Life, of excellence, of the fullest realization of human powers," so "sin as a failure in the effort to

\footnotetext{
* This paper is a result of the research conducted within the project "Protection of Human and Minority Rights in the European Legal Space" (No. 179046), which has been funded by the Ministry of Education, Science and Technological Development of the Republic of Serbia.

* Marko Trajković, Ph.D., Full Professor, trajkovicmarko@yahoo.com

${ }^{1}$ J. Finnis, Philosophy of Law, Volume IV, Oxford University Press, Oxford, 2011, 436.

${ }^{2}$ R. Mullerat, Conflict of Interest: Serving Two Masters, in Teaching Ethics, ed. by R. M Thomas, Centre for Business and Public sector Ethics, Cambridge, 201138.

${ }^{3}$ Ibid., 36.

${ }^{4}$ L. L. Fuller, The Morality of Law, Yale University Press, New Haven and London, 1964, 5.
} 
achieve a realization of the human quality itself." In the same way, Webster's New International Dictionary defines sin in the following way: "To depart voluntarily from the path of duty prescribed by God to man." And if we want to take the position of reason, we can use the idea that Greeks took because: "Generally with the Greeks instead of ideas of right and wrong, of moral claim and moral duty, we have rather the conception of proper and fitting conduct, conduct such as beseems a human being functioning at his best." It is possible that man is not judged "for failing to embrace opportunities for the fullest realization of their powers", but for "failing to respect the basic requirements of social living." ${ }^{8}$ We can conclude from this that the value reading of law is a kind of "deep play" since: "Every action must be appraised in the light of its contribution to the perfect life." ${ }^{10}$

\section{When Law is a Good Law?}

We can only then vote for a law, even if it is unjust or "(A) law which a man cannot obey, nor act according to it, is void and no law: and it is impossible to obey contradictions, or act according to them."11 One more thing that an unjust law can produce, and it is fast, is almost "everyday" change of law, which is characteristic for unstable legal systems, so, the following appears as a reaction: "A law that changes every day is worse than no law at all."12 Such a postulation directly introduces the conflict between justice and legal certainty, in order to protect man from "a bad system of law."13

It is then absolutely justified that: "Certainly there can be no rational ground for asserting that a man can have a moral obligation to obey a legal rule that does not exist, or is kept secret from him, or that came into existence only after he had acted, or was unintelligible, or was contradicted by another rule of the same system, or commanded the impossible, or changed every minute." 14 Thus, it is possible to create a legal system that will offer value and guarantee legal security, which is very important for the value reading of law. Of course, it does not mean anything without the other values. Since the second factual part of the legal order is human behavior by legal norms, it becomes quite clear why it is necessary that the value of legal certainty and absence of daily changes of legal norms is achieved, because "introducing such frequent changes in the rules that the subject cannot orient his action by them."15

\footnotetext{
${ }^{5}$ lbid., 3, f.. 1 .

${ }^{6}$ Ibid., 3.

${ }^{7}$ lbid., 5 .

${ }^{8}$ Ibid., 5-6.

${ }^{9}$ L. L. Fuller, The Morality of Law, 6.

${ }^{10}$ Ibid., 10.

${ }^{11}$ lbid., 33.

12 lbid., 37.

${ }^{13}$ Ibid., 39.

${ }^{14}$ Ibid.

${ }^{15}$ Ibid.
} 
Since legal norms exist and are directed towards people, "the legislator has a moral duty to make his laws clear and understandable." ${ }^{16}$ That is the only possible way to achieve a sense of the legal order. However, what appears as a problem in the functioning of the legal system is a constant "discrepancy between the law as declared and as actually administered"17, that does not occur only in unstable legal systems, it is a "thing" that is present in all legal systems. That is why Kant has the following idea: "We must not expect a good constitution because those who make it are moral men. Rather it is because of a good constitution that we may expect a society composed of moral men." ${ }^{18}$ However, the same as Plato, there is the issue how such imperfect people can create such perfect constitutions and laws. What is imposed as a conclusion by practice is the following: "Law has been often used as an instrument of legislative omnipotence. There was an attempt to make a whole nation sober by law. It failed." "The Italian dictator is trying to make his intelligent, cynical, and peace-loving people into courageous heroes. The fundamentalists have tried in some states of this Union to make people God-fearing and bibliolatric by law. A great communists Union has tried to abolish God, marriage, and the family, again by law." ${ }^{19}$ This is the problem of the past, present and future, because the affinity of man to arrange everything and to govern everything will never change.

That is why we quote Talmud: "If I am not for myself, who shall be for me? If I am for myself alone, what am I?" If we, according to Lon Fuller, "put this in the plural, we have, "If we are not for ourselves, who shall be for us? If we are for ourselves alone, what are we?"20 That is why we talk about the value reading of law because what we are if law is created only for us and obligations for others?

Of course, with the value reading of law, one starts from the language, which is the first level of reading, one from which all starts, but it is also very often the limiting factor because, according to Wittgenstein, "The limits of my language are the limits of my world." ${ }^{21}$ Thus begins the value reading of law, with its own language restriction, which then limits our understanding of the world and man. In this case we ask how language restricts the position and the role of judges, especially on the occasion of the value reading of law that is "Judge's moral authority". ${ }^{22}$ Such value reading of law is something that is expected from a legislator while creating laws, but in a special way it reflects the position and the role of the judge in, namely, functional legal order, because the court judgment directly realizes the part of the legal norms that affects the life of people in the "negative" way, the so-called sanctions. Therefore, it is particularly important for us that "Ronald Dworkin has urged American judges and lawyers to embrace the "moral reading of the (United States) Constitution." The moral reading insists that the Bill of Rights and the Fourteenth Amendment "invoke moral principles about the political decency and jus-

\footnotetext{
${ }^{16}$ Ibid., 43.

${ }^{17}$ L. L. Fuller, The Morality of Law, 81

${ }^{18}$ Ibid., 152.

${ }^{19}$ Ibid., 169.

20 lbid., 183.

${ }^{21}$ lbid., 186.

${ }^{22}$ S. Breyer, Introduction: The "International" Constitutional Judge, in Exploring Law's Empire, The Jurisprudence of Ronald Dworkin, ed. S. Hershovitz, Oxford University Press, Oxford, New York, 2006, 1.
} 
tice." ${ }^{23}$ Of course, the response is as follows: "Some critics worry that the moral reading emphasizes morality too much. They believe that it gives short shrift to text and history and that it calls upon judges to become philosophers instead of lawyers." ${ }^{24}$ However, we do not find anything wrong in the assumption that judges ought to be philosophers, actually this is required of them and they are not merely "screws" in the legal system, but can be creators, as well. This does not invoke mixing two governments, legislative and judicial, speaking of the need for judges to be not only independent, but also "creative" in difficult cases. This again does not mean that it invokes a situation where judges, especially in the postrevolutionary period, render judgments that are not based on the text of norms, but in the situation when the law does not say anything about something, when the laws have criminal content, this especially, because judges are not soldiers that can "hide" behind the famous phrase "I am a soldier and I just follow orders."

\section{Moral Principles and Reading the Law}

Since moral principles that can be built into general legal acts can be very abstract, such as the principle of "government must treat everyone as of equal status and with equal concern"25, it causes the need for legal acts to be often seen by philosophical methods, and they require a special "intellectual style"26 that would enable what Dworkin was referring to as "a fusion of constitutional law and moral philosophy."27 The question remains: "Can Dworkin's "moral reading" in fact accommodate historical argument and other traditional forms of legal reasoning, or does it require constitutional judges to become philosophers?" ${ }^{28}$ It is possible to come to nonmatching of moral values and the subsequent interpretation of general legal acts including the Constitution as the most important and the highest general legal act because: "For example, when Dworkin analyzes Equal Protection Clause, he says that there are only two possible interpretations of it. One possibility is that the Clause merely requires government to honor the terms of its laws, whatever those laws may say. If the law prohibits theft, then the police must enforce that law against anybody who steals, without regard to the race of the culprit or victim. This principle is very week one. It does not preclude the government from writing racially discriminatory terms straight into its laws; it merely prohibits the executive and judicial branches from discriminating when the legislature has no authorized them to do so."29 In this way, it becomes clear that the divergence of moral values and legal acts is absolutely possible. However, it remains an important place in the general value reading of law, the endeavor to include moral values in legal acts and to apply legal acts through them later.

\footnotetext{
${ }^{23}$ C. L. Eisgruber, Should Constitutional Judges be Philosophers?, in Exploring Law's Empire, The Jurisprudence of Ronald Dworkin, 5.

${ }^{24}$ Ibid.

${ }^{25}$ Ibid.

${ }^{26}$ C. L. Eisgruber, Should Constitutional Judges be Philosophers?, in Exploring Law's Empire, The Jurisprudence of Ronald Dworkin, 5.

${ }^{27}$ Ibid., 6.

${ }^{28}$ Ibid., 5.

${ }^{29}$ Ibid., 6.
} 
The value reading of law "refers to abstract moral principles and incorporates these by reference, as limits on government's power" and it "invokes moral principles about political decency and justice." ${ }^{30}$ This could be an adequate response to "dead hand"31 theories of law, representing only the emphasis on dogmatic-normative method. Very often there is the conflict between the value reading of law and absolute faith in the legal system, and, in many cases such as, for example, "Brown v. Board of Education" it happens that: "In their personal moral codes, these scholars could recognize a role for principle and could apply it to conclude that racial segregation was a bad thing, causing injustice. But their commitment to law as a system of rules, with no place for morality or principle, led them to argue that the power of judges recedes when the law runs out, leaving them no authority to resolve a constitutional issue by resort to principle." ${ }^{\text {23 }}$ Only with the value reading of law it is possible to enable law to "find its soul" ${ }^{33}$, since it often happens that: "One fascinating historical account of this period illustrates the schizophrenic condition of the academy with its frequent use, in describing the views of the theorists, of the qualifiers, "publicly" and "privately". Publicly the theorists would take one position, while privately, in correspondence, for example, they would hedge or qualify." 34

The value reading of law is also a condition "for moral membership in our political community are themselves preconditions for the legitimacy of the outcome of majoritarian political processes." ${ }^{35}$ Since nothing created by man is perfect, the value reading of law can help us to make our imperfect general legal acts somewhat acceptable, except those with criminal contents that do not deserve to be considered for legal acts because then the legal system would have "lost its Soul". ${ }^{36}$ Such legal systems reject the postulation that "moral rights" are "democratic conditions". 37 Such a climate has resulted in the situation that classes were destroyed by pure legal positivism, and: "He argued that the moral skeptics of the 1930s and 1940s were impoverished in their rejection of morality as part of law. The positivist emphasis on law as command with authority commensurate to its source in the people, erroneously limited law to a formal set of rules that had no use for morality in its enforcement and application. To Dworkin, this was an unacceptable mask to impose on law of any kind, but his attacks on positivism and utilitarianism had particular resonance for constitutional law. Because Dworkin saw law as a system of rights recognition and protection." ${ }^{38}$ The value reading of law enables law to

\footnotetext{
${ }^{30}$ lbid., 9, f. 16.

${ }^{31}$ Ibid., 19.

${ }^{32}$ R. L. Braun, How Constitutional Theory Found its Soul: The Contributions of Ronald Dworkin, in Exploring Law's Empire, The Jurisprudence of Ronald Dworkin, 45.

${ }^{33}$ Ibid., 41.

${ }^{34}$ Ibid., 45.

$35 \mathrm{~J}$. E. Fleming, The Place of History and philosophy in the Moral Reading of the American Constitution, in Exploring Law's Empire, The Jurisprudence of Ronald Dworkin, 27.

${ }^{36}$ R. L. Braun, How Constitutional Theory Found its Soul: The Contributions of Ronald Dworkin, in Exploring Law's Empire, The Jurisprudence of Ronald Dworkin, 42.

${ }^{37} \mathrm{~J}$. E. Fleming, The Place of History and philosophy in the Moral Reading of the American Constitution, in Exploring Law's Empire, The Jurisprudence of Ronald Dworkin, 29.

${ }^{38}$ R. L. Braun, How Constitutional Theory Found its Soul: The Contributions of Ronald Dworkin, in Exploring Law's Empire, The Jurisprudence of Ronald Dworkin, 49.
} 
introduce the principles into general legal acts that would again be "recognition of moral rights against the government". ${ }^{39}$

The value reading of law at the same time helps the judges who do not doubt legal acts that protect man from his government because: "Courts are moral actors, and a court can display integrity in much the same way that an individual can." ing of law becomes especially important in situations which can be referred to as discretion, so Hart "says that when the judge's discretion is in play, we can no longer speak of his being bound by standards, but must speak rather of what standards he "characteristically uses." The discretion of a judge to decide is particularly evident in difficult cases, especially if we accept the attitude of nominalists that: "judges always have discretion, even when a clear rule is in point, because judges are ultimately the final arbiters of the law." ${ }^{\prime 2}$ Yet, his discretion "means not that he is free to decide without recourse to standards of sense and fairness, but only that his decision is not controlled by a standard furnished by the particular authority we have in mind when we raise the question of discretion." ${ }^{43}$ Therefore, his reading of law is not by discretion itself free of moral values, so a judge, as anybody else, is "bound to follow the principle that no man profit from his own wrong"44 which happened in 1889 in New York in the case Riggs v. Palmer, when the court "had to decide whether an heir named in the will of his grandfather could inherit under that will, even though he had murdered his grandfather to do so." Thus: "The judge who looks outside the Constitution always looks inside himself and nowhere else." ${ }^{46}$ We can only conditionally agree with this attitude because we want to avoid subjectivity, therefore, judges do not face only their own view of reality, but also regulations provided and guaranteed by the state and the moral values of the society, as well as the value reading of law. This shows the tension in coming to "happy endings" between "strict adherence to legal norms and their logical implications, and on the other hand, the entirely understandable urge to "do justice"-as the judges see it-to the flesh and blood individuals who stand before them". ${ }^{47}$ The case Riggs v. Palmer showed that it was not true that "moral reasoning is too subjective, mystifying, and irresolvable to rely on in legal contexts. Were moral reasoning necessarily embedded in legal argument, it would only infect the law with endless controversies characteristic of morality. This would be especially intolerable in the law, since the main function of law is to settle disputes, put an end to argument, and get on with deploying the state's power in an orderly way." ${ }^{48}$ It pointed out the following: "We all know that there are "hard cases" where the law is to some extent indeterminate, as when it is ambiguous,

\footnotetext{
${ }^{39}$ Ibid.

${ }^{40}$ S. Hershovitz, Integrity and Stare Decisis, in Exploring Law's Empire, The Jurisprudence of Ronald Dworkin, 115.

${ }^{41}$ R. Dworkin, The Model of Rules I, in C. Johnosn, Philosophy of Law, New York, 1993, 109.

${ }^{42}$ Ibid.

${ }^{43}$ Ibid.

${ }^{44}$ Ibid.

${ }^{45}$ Ibid., 101.

${ }^{46}$ S. Macedo, Morality and Constitutional Law, in: C. Johnson, Philosophy of Law, 425.

${ }^{47}$ J. Goldsworthy, The Limits of Judicial Fidelity to Law: The Coxford Lecture, Faculty of Law, Monash University, Reasercs Paper, No 2011/14, 307.

${ }^{48}$ C. Johnson, Legal Reasoning and Its Conceptual Tools, in C. Johnson, Philosophy of Law, 366.
} 
vague, inconsistent, insufficiently explicit or even silent as to issues that judges must resolve. Judges must resolve disputes properly brought before them, and when the law does not resolve them, they must act creatively and make new law, guided by political morality." ${ }^{49}$ Thus, we must disagree with the opinion of Posner on "value judgements": (It is) inevitable that many judicial decisions will be based on value judgements rather that technical determination not scientific, and therefore are not readily falsifiable and hence not readily verifiable either and as a consequence are not always profitably discussable." ${ }^{50}$ Of course, in these cases there is a danger of subjectivism, but it can be overcome by the constant construction of value mentality because: "It is important in a democracy in which the governed are conceived to be free persons that the actions of officials, ranging from judicial decisions to enactments of the legislature, be based on a foundation of moral defensibility. It is not enough to say, "This is our decision; it needs no justification other that our power." The giving of orders backed by nothing else than threats and cutting off all requests for moral justification might promote legal certainty, but it is not the giving of law to free people. As one writer puts it, "the public morality of law creates a certain kind of moral community, one in which political official answers to the public not only for following the rules but also for their conscientious adherence to shared political principles." ${ }^{51}$ Is it then possible that discretion allows for judges the "legitimate scope for creativity"?

\section{Conclusion}

The value reading of law also requires the construction of value mentality and integrity as Dworkin said "Integrity becomes a political ideal when ... we insist that the state act on a single coherent set of principle even when its citizens are divided about what the right principles of justice and fairness really are. We assume, in both the individual and political cases, that we can recognize other people's acts as expressing a conception of justice or decency even when we do not endorse that conception ourselves, this ability is important part of our more general ability to treat others with respect, and it is therefore a prerequisite of civilization." ${ }^{53}$ What the value reading of law shows us is that states and governments cannot act "capriciously in matters of importance", and "we want the state to strive to act morally", as well as the creation of "coherent vision of what we owe to one another."

The value reading of law and the ideal of integrity "requires government to speak with one voice, to act in a principled and coherent manner toward all its citizens, to extend to everyone the same substantive standards of justice or fairness it uses for some." ${ }^{55}$ Thus,

\footnotetext{
49 J. Goldsworthy, The Limits of Judicial Fidelity to Law: The Coxford Lecture, 307.

${ }^{50}$ S. Macedo, Morality and Constitutional Law, in: C. Johnson, Philosophy of Law, 426.

${ }^{51}$ C. Johnson, Legal Reasoning and Its Conceptual Tools, in C. Johnson, Philosophy of Law, 367.

52 J. Goldsworthy, The Limits of Judicial Fidelity to Law: The Coxford Lecture, 307.

${ }^{53}$ S. Hershovitz, Integrity and Stare Decisis, in Exploring Law's Empire, The Jurisprudence of Ronald Dworkin, 115.

${ }^{54}$ Ibid., 115-116.

${ }^{55}$ D. Smith, The Many Faces of Political Integrity, in Exploring Law's Empire, The Jurisprudence of Ronald Dworkin, 120.
} 
it is true that "most eminent non-positivist, Ronald Dworkin, acknowledges that on rare occasions the law might be so unjust that even judges morally ought to disobey it." Thus, a judge becomes a real guardian of legality if we do not understand the law in formal legal sense, because "a judge is confronted with having to deliver a judgment that seems to him... to contain too much law and not enough justice" ${ }^{n 7}$, all this because, according to Oliver Wendell Holmes Jr. "the life of the law has not been logic....". Therefore, we are back on the ground of the claim that the link between faith and reason in every kind of social activity is necessary, and thus in legal industry understood in the widest possible way.

\section{Bibliography}

[1] Exploring Law's Empire, The Jurisprudence of Ronald Dworkin, ed. S. Hershovitz, Oxford University Press, Oxford, New York, 2006.

[2] Finnis, J, Philosophy of Law, Volume IV, Oxford University Press, Oxford, 2011.

[3] Fuller, L. L, The Morality of Law, Yale University Press, New Haven and London, 1964.

[4] Goldsworthy, J, The Limits of Judicial Fidelity to Law: The Coxford Lecture, Faculty of Law, Monash University, Reasercs Paper, No 2011/14.

[5] Johnson, C, Philosophy of Law, New York, 1993.

[6] Teaching Ethics, ed. by R. M Thomas, Centre for Business and Public sector Ethics, Cambridge, 2011.

\footnotetext{
${ }^{56} \mathrm{~J}$. Goldsworthy, The Limits of Judicial Fidelity to Law: The Coxford Lecture, 308.

${ }^{57}$ Ibid., 315.

${ }^{58} \mathrm{~J}$. Goldsworthy, The Limits of Judicial Fidelity to Law: The Coxford Lecture, 324.
} 